\title{
Effect of Pruning on Apple Scab in Organic Apple Production
}

\author{
I. J. Holb, Department of Plant Protection, University of Debrecen, Centre of Agricultural Sciences, P.O. Box 36, \\ H-4015 Debrecen, Hungary
}

\begin{abstract}
Holb, I. J. 2005. Effect of pruning on apple scab in organic apple production. Plant Dis. 89:611618.

In a 3-year Hungarian study, the effectiveness of apple tree pruning as a management tactic for control of apple scab (Venturia inaequalis) was investigated on two susceptible (cvs. Jonagold and Mutsu), two moderately susceptible (cvs. Elstar and Idared), and two $V_{f}$ resistant apple cultivars (cvs. Liberty and Prima) in three high-density organic apple orchards treated with copperand sulfur-based fungicide programs. The area under the disease progress curve (AUDPC) for leaf and fruit incidences was calculated to evaluate three winter pruning treatments (unpruned, weakly pruned, and strongly pruned). Strong pruning significantly decreased leaf scab on the susceptible and the moderately susceptible cultivars at all sites compared with unpruned ones. Moreover, for the cultivar Jonagold in all years and for the cultivar Mutsu in 2001, AUDPC values of strongly pruned trees were significantly lower at $P=0.05$ compared with the weakly pruned trees. The effect of pruning on development of fruit scab was weaker than on leaf scab in all years and at all sites. For fruit scab incidence on susceptible cultivars, only strong pruning treatments decreased AUDPC significantly compared with unpruned treatments. The effects of pruning treatments on moderately susceptible cultivars were significant only in 2001 at all sites. Resistant cultivars showed no significant effect of pruning treatments on development of either fruit or leaf scab except for cultivar Liberty in 2001 at one site. Pruning resulted in no consistent difference in the apple tree canopy microclimate. However, strong pruning resulted in improved spray deposition in the tree canopy when applications were made with an airblast sprayer at midsummer. Results are compared with similar studies, and their biological interpretation is discussed.
\end{abstract}

Additional keywords: cultural control, disease incidence, integrated pest management, plant canopy microclimate, potential ascospore dose, scab control

The fungus Venturia inaequalis (Cooke) G. Wint. (anamorph: Spilocaea pomi Fr.:Fr.) causes scab of apple (Malus $\times$ domestica Borkh.) and is common on apple leaves and fruits in temperate growing regions (29). Weather often provides suitable conditions for severe scab epidemics in Hungary, and 10 to $30 \%$ of apple fruits are consequently downgraded when marketed (16). Therefore, frequent fungicide applications (10 to 18 annually) are needed to control apple scab. As consumers increasingly demand apples free of chemical residues and as environmental considerations become more important, interest in organic fruit production is growing all over the world $(9,10,35,37,45)$. The organization International Federation of Organic Agriculture Movements (IFOAM) and, recently, the U.S. Department of Agriculture through the National Organic Program (NOP) fully implemented their standards for organic crop production outlining the

Corresponding author: I. J. Holb

E-mail: holb@helios.date.hu

Accepted for publication 10 January 2005.

DOI: 10.1094/PD-89-0611

(C) 2005 The American Phytopathological Society criteria that must be met to label agricultural products as "organic" $(23-25,37)$. According to both IFOAM and NOP standards, organic production allows products such as biologicals (Trichoderma spp.), minerals (soluble rock powder), elemental and lime sulfur, hydrated lime, and mechanical methods (trap). However, only a few approved fungicidal products are available for organic scab control, such as sulfur and copper compounds, and these are less effective and more phytotoxic than modern synthetic fungicides $(6,10,17-19)$.

In order to lessen the risk of scab epidemics, research was begun to evaluate nonspraying management options (29), but tree pruning has received little attention in scab control. Tree pruning is performed primarily for modification of tree form for optimum production of high-quality apples. However, mechanical modification of the canopy can also alter the microclimate and prevent or abate disease $(5,11,46)$; therefore, the authors concluded that pruning might also be a useful disease management option. The effect of pruning on the incidence of flyspeck and sooty blotch has been studied. Latham and Hollingsworth (27), Ocamb-Basu et al. (33), and Cooley et al. $(4,5,7)$ observed that flyspeck and sooty blotch on apple often are more severe in unpruned trees than in pruned ones. They suggested that pruning improves drying in the apple tree canopy and can be used to reduce the incidence of flyspeck or sooty blotch. No scientific study has been performed on the effect of pruning on apple scab. If pruning could reduce incidence of apple scab, it might also suppress scab development and epidemics in infested organic apple orchards, depending on cultivar susceptibility.

The aim of the 3-year study was to determine whether pruning has an effect on the development of apple scab under a continental climate, and if so, to determine how scab development is affected by the degree of pruning, cultivar susceptibility, and location in high-density organic apple orchards treated with copper- and sulfurbased fungicide programs. The effect of pruning on apple tree canopy microclimate and spray deposition was also studied.

\section{MATERIALS AND METHODS}

Orchard sites, plant materials, and spray schedules. The studies were conducted during 2000, 2001, and 2002 in three organic commercial apple orchards in Hungary. One of the orchards was located at $47^{\circ} 31^{\prime} 60^{\prime \prime} \mathrm{N}$ and $21^{\circ} 37^{\prime} 60^{\prime \prime} \mathrm{E}$, in Nagykálló, Eastern Hungary. The other two orchards were in Debrecen-Józsa and Eperjeske, $33 \mathrm{~km}$ south and $89 \mathrm{~km}$ north of the orchard at Nagykálló, respectively.

In Nagykálló, the 3.2-ha orchard consisted of seven apple cultivars, with a minimum of 500 trees of each cultivar. This orchard consisted of 44 rows, with a distance between rows of $4 \mathrm{~m}$ and within a row of $1.5 \mathrm{~m}$. In Debrecen-Józsa, the 12.5ha orchard consisted of seven apple cultivars, with a minimum of 600 trees of each cultivar. This orchard consisted of 80 rows, with a distance between rows of $4 \mathrm{~m}$ and within a row of $1.5 \mathrm{~m}$. In Eperjeske, the area of the orchard used in our study was 6.8 ha. It consisted of eight apple cultivars, with a minimum of 500 trees of each cultivar. This orchard consisted of 48 rows, with a distance between rows of $5 \mathrm{~m}$ and within a row of $2 \mathrm{~m}$. In the three orchards, all trees were on M26 rootstocks and pruned to spindle shape and planted in 1996, except for Debrecen-Józsa, where trees were on M9 rootstocks.

Hungarian organic production guidelines (1) derived from the IFOAM standards $(23,24)$ have been applied since the planting of all three orchards. Spray schedules against apple scab in 2000, 2001, and 2002 in the three orchards are given in Table 1. 
Selected cultivars and experimental design. Three cultivars, one $V_{f}$-resistant (scab resistance is conditioned by a single gene, designated $V_{f}$ [47], with the $V$ referring to Venturia and the $f$ referring to the resistance source, $M$. floribunda), one moderately susceptible, and one susceptible to apple scab, were selected for the pruning treatments for each of the three orchards. The selected $V_{f}$-resistant cultivars $(8,26)$ were Liberty at Nagykálló, and Prima at Debrecen-Józsa and Eperjeske; the moderately susceptible cultivars $(16,32)$ were Elstar at Nagykálló and Debrecen-Józsa, and Idared at Eperjeske; and the susceptible cultivars $(16,34)$ were Jonagold at Nagykálló and DebrecenJózsa, and Mutsu at Eperjeske.

Three pruning treatments were performed from 2000 to 2002 in each of the three orchards. Treatments were in four replicates for each of the three cultivars. Each treatment replicate plot consisted of 14 trees at each site. As cultivars were in one block at each site, the pruning treatments were in a completely randomized design (CRD) for each cultivar and site (14). In treatment 1 , trees were unpruned, in treatments 2 and 3 , trees were weakly and strongly pruned, respectively. In treat- ment 2, the crown of a tree was reduced to 90 to $95 \%$ by removing only 1 -year-old twigs. In treatment 3 , the crown of a tree was reduced to 75 to $80 \%$ by removing 1and 2-year-old twigs and, if necessary, the 3-year-old twigs. Pruning was performed once a year in February, before bud break, in all three orchards (Table 2).
Potential ascospore dose. In spring, the potential ascospore dose (PAD) was calculated in each orchard according to Gadoury and MacHardy (12). The mean number of scab lesions per square meter of leaf at leaf fall (lesion density $=\mathrm{LD}$ ) was recorded at the end of October in 1999, 2000, and 2001 (Table 2). The proportion of the or-

Table 2. Dates of sampling and pruning in the organic apple orchards at Nagykálló, Debrecen-Józsa, and Eperjeske, Hungary (1999-2002)

\begin{tabular}{|c|c|c|c|c|}
\hline $\begin{array}{l}\text { Location and } \\
\text { season }\end{array}$ & $\begin{array}{c}\mathrm{LD}^{\mathbf{y}} \\
\text { assessment }\end{array}$ & Pruning & $\begin{array}{c}\mathbf{L L D}^{\mathbf{z}} \\
\text { assessment }\end{array}$ & $\begin{array}{c}\text { Weather recording } \\
\text { period }\end{array}$ \\
\hline \multicolumn{5}{|l|}{ Nagykálló } \\
\hline 1999 & 25 October & $\ldots$ & $\ldots$ & $\ldots$ \\
\hline 2000 & 29 October & 22 February & 27 February & 10 March to 11 October \\
\hline 2001 & 31 October & 24 February & $3 \mathrm{March}$ & 10 March to 14 October \\
\hline 2002 & $\ldots$ & 26 February & $6 \mathrm{March}$ & 15 March to 15 October \\
\hline \multicolumn{5}{|l|}{ Debrecen-Józsa } \\
\hline 1999 & 22 October & . & $\ldots$ & \\
\hline 2000 & 31 October & 15 February & 27 February & 11 March to 10 October \\
\hline 2001 & 27 October & 25 February & $1 \mathrm{March}$ & 20 March to 16 October \\
\hline 2002 & $\ldots$ & 23 February & 25 February & 15 March to 15 October \\
\hline \multicolumn{5}{|l|}{ Eperjeske } \\
\hline 1999 & 27 October & $\ldots$ & $\ldots$ & . \\
\hline 2000 & 30 October & 22 February & 23 February & 10 March to 10 October \\
\hline 2001 & 28 October & 28 February & $4 \mathrm{March}$ & 12 March to 15 October \\
\hline 2002 & $\ldots$ & 14 February & 26 February & 15 March to 11 October \\
\hline
\end{tabular}

${ }^{\mathrm{y}}$ Lesion density: lesion number per square meter of leaf.

${ }^{\mathrm{z}}$ Leaf litter density: proportion of orchard floor covered by leaf litter.

Table 1. Spray schedules against apple scab in the organic apple orchards at Nagykálló, Debrecen-Józsa, and Eperjeske, Hungary (2000-2002)

\begin{tabular}{|c|c|c|c|c|c|c|c|c|c|c|c|}
\hline \multicolumn{4}{|c|}{ Nagykálló } & \multicolumn{4}{|c|}{ Debrecen-Józsa } & \multicolumn{4}{|c|}{ Eperjeske } \\
\hline Date & $\begin{array}{l}\text { Phenolog. } \\
\text { stage }\end{array}$ & Trade name $^{\mathrm{z}}$ & Dos. & Date & $\begin{array}{l}\text { Phenolog. } \\
\text { stage }\end{array}$ & Trade name $^{\mathrm{z}}$ & Dos. & Date & $\begin{array}{l}\text { Phenolog. } \\
\text { stage }\end{array}$ & Trade name ${ }^{\mathrm{z}}$ & Dos. \\
\hline 2000 & & & & 2000 & & & & 2000 & & & \\
\hline 4 Apr & Green tip & Cuproxat FW & $0.1 \%$ & $1 \mathrm{Apr}$ & Green tip & Rézoxiklorid 50WP & $0.3 \%$ & $27 \mathrm{Mar}$ & Green tip & Funguran-OH & $0.1 \%$ \\
\hline $10 \mathrm{Apr}$ & Tight cluster & Cuproxat FW & $0.1 \%$ & $12 \mathrm{Apr}$ & Tight cluster & Rézkén 650FW & $0.3 \%$ & & & Kumulus S & $0.2 \%$ \\
\hline \multirow{2}{*}{$\begin{array}{l}26 \text { Apr, } \\
9,16,25 \text { May, } \\
2 \text { Jun, } \\
17 \text { Jul }\end{array}$} & \multirow[t]{2}{*}{$\begin{array}{l}\text { After tight } \\
\text { cluster }\end{array}$} & \multirow[t]{2}{*}{$\begin{array}{l}\text { Szulfur } \\
\text { 900FW }\end{array}$} & \multirow[t]{2}{*}{$0.4 \%$} & \multirow{2}{*}{$\begin{array}{l}24 \text { Apr, } \\
\text { 11, 19, } 27 \text { May, } \\
2,11,17 \text { Jun, } \\
17 \text { Jul }\end{array}$} & \multirow[t]{2}{*}{$\begin{array}{l}\text { After tight } \\
\text { cluster }\end{array}$} & \multirow[t]{2}{*}{ Kumulus S } & \multirow[t]{2}{*}{$0.4 \%$} & 4 Apr & Tight cluster & $\begin{array}{l}\text { Funguran-OH } \\
\text { Kumulus S }\end{array}$ & $\begin{array}{l}0.1 \% \\
0.2 \%\end{array}$ \\
\hline & & & & & & & & $\begin{array}{l}\text { 12, 19, } 26 \text { Apr, } \\
3,11,19,27 \text { May, } \\
2,11,19,27 \text { Jun, } \\
5,21,31 \text { Jul, } \\
12 \text { Aug }\end{array}$ & $\begin{array}{l}\text { After tight } \\
\text { cluster }\end{array}$ & Kumulus S & $0.4 \%$ \\
\hline 2001 & & & & 2001 & & & & 2001 & & & \\
\hline 27 Mar & Bud break & Cuproxat FW & $0.1 \%$ & $29 \mathrm{Mar}$ & Bud break & Rézoxiklorid 50WP & $0.3 \%$ & $26 \mathrm{Mar}$ & Green tip & Funguran-OH & $0.1 \%$ \\
\hline $5 \mathrm{Apr}$ & Green tip & Cuproxat FW & $0.1 \%$ & $8 \mathrm{Apr}$ & Green tip & Rézoxiklorid 50WP & $0.3 \%$ & & & Kumulus S & $0.2 \%$ \\
\hline \multirow{2}{*}{$\begin{array}{l}\text { 12, 19, } 25 \text { Apr, } \\
11,19,27 \text { May, } \\
5,15,27 \text { Jun, } \\
19 \text { Jul }\end{array}$} & \multirow[t]{2}{*}{$\begin{array}{l}\text { After green } \\
\text { tip }\end{array}$} & \multirow[t]{2}{*}{$\begin{array}{l}\text { Szulfur } \\
\text { 900FW }\end{array}$} & \multirow[t]{2}{*}{$0.4 \%$} & \multirow{2}{*}{$\begin{array}{l}\text { 15, 22, } 30 \text { Apr, } \\
6,18,25 \text { May, } \\
\text { 4, 12, } 21 \text { Jun, } \\
\text { 12 Jul }\end{array}$} & \multirow[t]{2}{*}{$\begin{array}{l}\text { After green } \\
\text { tip }\end{array}$} & \multirow[t]{2}{*}{ Tiosol } & \multirow[t]{2}{*}{$1.0 \%$} & $3 \mathrm{Apr}$ & Tight cluster & $\begin{array}{l}\text { Funguran-OH } \\
\text { Kumulus S }\end{array}$ & $\begin{array}{l}0.1 \% \\
0.2 \%\end{array}$ \\
\hline & & & & & & & & $\begin{array}{l}\text { 10, 18, } 27 \text { Apr, } \\
1,8,14,23 \text { May, } \\
1,10,18,25 \text { Jun, } \\
4,14,22,29 \text { Jul, } \\
10 \text { Aug }\end{array}$ & $\begin{array}{l}\text { After tight } \\
\text { cluster }\end{array}$ & Kumulus S & $0.4 \%$ \\
\hline 2002 & & & & 2002 & & & & 2002 & & & \\
\hline 25 Mar & Bud break & Cuproxat FW & $0.1 \%$ & $1 \mathrm{Apr}$ & Bud break & Rézoxiklorid 50WP & $0.3 \%$ & 27 Mar & Green tip & Funguran-OH & $0.1 \%$ \\
\hline $6 \mathrm{Apr}$ & Green tip & Cuproxat FW & $0.1 \%$ & 15 Apr & Green tip & Rézoxiklorid 50WP & $0.3 \%$ & & & Kumulus S & $0.2 \%$ \\
\hline \multirow{2}{*}{$\begin{array}{l}\text { 15, } 23 \mathrm{Apr}, \\
\text { 3, 8, 18, 28, } 31 \mathrm{M} \\
\text { 3, 13 Jun, } \\
\text { 1, 8 Jul, } \\
\text { 8, 15 Aug }\end{array}$} & \multirow{2}{*}{$\begin{array}{l}\text { After green } \\
\text { Iay, tip }\end{array}$} & \multirow[t]{2}{*}{$\begin{array}{l}\text { Szulfur } \\
\text { 900FW }\end{array}$} & \multirow[t]{2}{*}{$0.4 \%$} & \multirow{2}{*}{$\begin{array}{l}\text { 23, } 27 \text { Apr, } \\
5,13,20,29 \text { May, } \\
2,11,14 \text { Jun, } \\
18 \text { Jul }\end{array}$} & \multirow[t]{2}{*}{$\begin{array}{l}\text { After } \\
\text { green tip }\end{array}$} & \multirow[t]{2}{*}{ Tiosol } & \multirow[t]{2}{*}{$1.0 \%$} & $6 \mathrm{Apr}$ & Tight cluster & $\begin{array}{l}\text { Funguran-OH } \\
\text { Kumulus S }\end{array}$ & $\begin{array}{l}0.1 \% \\
0.2 \%\end{array}$ \\
\hline & & & & & & & & $\begin{array}{l}\text { 15, 21, } 29 \text { Apr, } \\
\text { 5, 14, 24,31 May, } \\
7,15,23,30 \text { Jun, } \\
\text { 7, 16, 24, } 31 \text { Jul, } \\
15 \text { Aug }\end{array}$ & $\begin{array}{c}\text { After tight } \\
\text { cluster }\end{array}$ & Kumulus S & $0.4 \%$ \\
\hline
\end{tabular}

\footnotetext{
${ }^{\text {z }}$ Cuproxat FW: 350 g/liter copper sulfate, NuFarm Ltd., Linz, Austria; Szulfur 900FW: 900 g/liter elementary sulfur, Budapesti Vegyimüvek GmbH, Budapest, Hungary; Rézoxiklorid 50WP: 50\% copper oxychloride, Agroterm Ltd., Peremarton, Hungary; Rézkén 650FW: 200 g/liter copper oxychloride and 450 g/liter elementary sulfur, Nitrokémia $2000 \mathrm{GmbH}$, Füzfö, Hungary; Kumulus S: 80\% elementary sulfur, BASF Hungaria Ltd., Budapest, Hungary; Tiosol: 29\% calcium polysulfides, Tiosol Ltd., Kistelek, Hungary; Funguran-OH 50WP: 77\% copper hydroxide, Spiess-Urania Chemicals GmbH, Hamburg, Germany.
} 
chard floor covered by leaf litter at bud break (leaf litter density = LLD) was also determined in 2000, 2001, and 2002 (Table 2). Observations were carried out in 10 replicates by examining 200 randomly chosen leaves from the pruning treatment plots. For all years and all orchard sites, pseudothecial density (PD) and ascal density (AD) were based on 30.2 mature pseudothecia per visible lesion and 122.3 asci per pseudothecium, respectively (12). PAD was calculated as the average of 10 replicates for each year and orchard site.

Environmental monitoring. Leaf wetness duration (h), relative humidity (\%), rainfall $(\mathrm{mm})$, and temperature $\left({ }^{\circ} \mathrm{C}\right)$ were detected at 12-min intervals using Metos Compact agrometeorological stations (Pessl Instrument GmbH, Weiz, Austria) in all orchards from mid-March until midOctober in 2000, 2001, and 2002 (Table 2). The agrometeorological stations were located at about 50,40 , and $30 \mathrm{~m}$ southwest of the experimental plots in the orchards at Nagykálló, Debrecen-Józsa, and Eperjeske, respectively, during each season. Sensors were mounted $1 \mathrm{~m}$ above the ground in the center of the canopy of a tree during each season at each site. Apple scab infection periods were calculated according to Mills and LaPlante (30) for each location and each year. In the experimental plots, a hygrothermograph (Techno Ltd., Budapest, Hungary) was mounted $1 \mathrm{~m}$ above the ground in the center of the canopy of a strongly pruned and an unpruned tree during each season at each site.

Spray deposition in pruned and unpruned trees. Fifteen apple trees (2.4 to $2.8 \mathrm{~m}$ tall and 1.3 to $1.7 \mathrm{~m}$ wide) were randomly assigned to five blocks of three trees each. In each block, the first tree was weakly pruned, the second strongly pruned, and the third not pruned. Pruning was performed in 2002 before bud break on 22, 24, and 26 February at Nagykálló, Debrecen-Józsa, and Eperjeske, respectively. The experiment was conducted on cv. Jonagold at Nagykálló and Debrecen-
Józsa and cv. Mutsu at Eperjeske. On 2 May ( 2 weeks after fruit set) and 3 July (full tree canopy size), 2002, 12 watersensitive paper targets $(3 \times 8 \mathrm{~cm})$ were systematically attached to twigs in each tree. Four targets were placed at each of three heights: lower $(0.7 \mathrm{~m}$ from the ground), middle $(1.5 \mathrm{~m})$, and upper canopies $(2.2 \mathrm{~m})$. At each height, two targets were placed outside the canopy (within 10 $\mathrm{cm}$ of the edge of the canopy) and two targets were placed inside the canopy (within $10 \mathrm{~cm}$ of the tree trunk). Water was applied to the trees directly with a commercial airblast sprayer delivering 1,000 liters/ha and traveling at $5 \mathrm{~km} / \mathrm{h}$. Resulting spray deposition patterns on the papers were digitalized directly from the watersensitive papers using a digital camera (Nikon Coolpix 4500, Nicon Corporation, Tokyo, Japan). Digitalized images were analyzed using image analysis software (Colim colour image measuring system, version 2.1, Pictron Ltd., Budapest, Hungary) on a personal computer.

Disease assessments. Disease assessments were made on leaves and fruits every 3 to 4 weeks from 1 April until 10 October in each year at each site. Observations were made on each tree of each treatment replicate. For leaf assessment, five 1-year-old woody lateral twigs were selected on each observed tree and at each assessment date. On each selected twig, disease was assessed on 50 leaves counted from the top of the shoot. For fruit assessment, 25 fruits typical for the given phenological stage were observed on each tree and at each assessment date. Leaves and fruits were considered to be diseased if at least one visible scab lesion was present on one leaf or fruit.

Leaf and fruit scab incidence were calculated as the percentage of leaves and fruits with at least one scab lesion, respectively. For each pruning treatment, the temporal dynamics of leaf and fruit scab epidemics were summarized in the area under the disease progress curve (AUDPC)
(2). AUDPC (percent-days) was calculated as:

$$
\mathrm{AUDPC}=\sum_{i}^{n-1}\left(\frac{y_{i}+y_{i+1}}{2}\right) \times\left(t_{i+1}-t_{i}\right)
$$

where $n$ is the total number of assessments, $y_{i}$ is disease incidence at the $i$ th assessment date, and the term $t_{i+1}-t_{i}$ is the time duration between two assessments.

Leaf and fruit scab severity as well as corresponding AUDPC were also calculated, but the significant differences between treatments for severity were similar to those for incidence; therefore, only incidence values were retained for analysis.

Statistical analyses. Disease assessment data from the three locations were analyzed separately. Calculated AUDPC values were divided into two data sets, one for leaf incidence and the other for fruit incidence. Both data sets were subjected to analysis of variance (ANOVA) using the Genstat 5 Release 4.1 statistical package (Lawes Agricultural Trust, IACR, Rothamsted, UK) in order to determine the effect of year, pruning, cultivar, and their interactions on AUDPC values. Then, for each cultivar and for each year, significant $F$ tests $(P=0.05)$ were followed by a least significant difference (LSD) test for comparison of pruning treatment means using $\mathrm{LSD}_{0.05}$ values. Spray deposition data were analyzed by computing the water-darkened area as a percentage of a uniform area (25 $\times 40 \mathrm{~mm}$ ) of each target. Means were separated using $\mathrm{LSD}_{0.05}$ values.

\section{RESULTS}

Potential ascospore dose. At each site, the mean lesion density (LD) ranged from 311 to 477 lesions per square meter of leaf at leaf fall, and the mean leaf litter density (LLD) was between 31.5 and $45.2 \%$ at bud break for the 3 years (Table 3). The mean production of ascospores per square meter of orchard floor (PAD) was 104,821 to 169,547 ascospores per square meter (Table 3), which shows that production of primary inoculum was high compared with

Table 3. Estimated potential ascospore dose (PAD) of Venturia inaequalis in organic apple orchards at Nagykálló, Debrecen-Józsa, and Eperjeske, Hungary (2000-2002)

\begin{tabular}{|c|c|c|c|c|c|c|}
\hline \multirow{2}{*}{$\begin{array}{l}\text { Location and } \\
\text { season }\end{array}$} & \multicolumn{2}{|c|}{$\mathbf{L D}^{\mathrm{w}}$} & \multicolumn{2}{|c|}{$\mathbf{L L D}^{\mathrm{x}}$} & \multicolumn{2}{|c|}{ PAD $^{y}$} \\
\hline & Estimate & $\mathbf{S E}^{\mathbf{z}}$ & Estimate & SE & Estimate & SE \\
\hline \multicolumn{7}{|l|}{ Nagykálló } \\
\hline 2000 & 362 & 29.8 & 40.7 & 5.5 & 130,601 & 7,345 \\
\hline 2001 & 467 & 44.3 & 37.4 & 6.4 & 154,822 & 8,467 \\
\hline 2002 & 448 & 47.5 & 39.5 & 4.8 & 156,862 & 14,467 \\
\hline \multicolumn{7}{|l|}{ Debrecen-Józsa } \\
\hline 2000 & 335 & 36.2 & 35.3 & 6.2 & 104,821 & 9,345 \\
\hline 2001 & 378 & 28.3 & 39.4 & 7.3 & 132,013 & 12,456 \\
\hline 2002 & 411 & 49.2 & 31.5 & 7.1 & 114,757 & 8,234 \\
\hline \multicolumn{7}{|l|}{ Eperjeske } \\
\hline 2000 & 311 & 38.2 & 45.2 & 7.3 & 124,603 & 5,235 \\
\hline 2001 & 422 & 40.1 & 43.2 & 10.2 & 163,891 & 14,325 \\
\hline 2002 & 477 & 47.8 & 40.1 & 11.5 & 169,547 & 17,345 \\
\hline
\end{tabular}

\footnotetext{
${ }^{\mathrm{w}}$ Lesion density: lesion number per square meter of leaf.

$\mathrm{x}$ Leaf litter density: proportion of the orchard floor covered by leaf litter.

y Potential ascospore dose: ascospore number per square meter of orchard floor.
}

${ }^{\mathrm{z}}$ Standard error. 
an integrated orchard in all years and at all sites.

Environmental conditions. Environmental conditions for scab infection were variable among the three seasons and the three sites (Table 4). The number of infection periods from mid-March until midOctober ranged among sites from 15 to 17 in 2000, 22 to 25 in 2001, and 21 to 24 in 2002. Environmental conditions for scab infections were more favorable in 2001 and 2002 than in 2000 at all sites. There were no consistent differences in temperature or relative humidity within canopies of strongly pruned or unpruned trees (data not shown).

Spray deposition in pruned and unpruned trees. The percentage of area wetted by spray deposition did not increase significantly $(7.3 \% ; P=0.097)$ on 2 May; however, the increase of deposition $(23.1 \%)$ was significant $(P=0.033)$ on 3 July in strongly pruned trees compared with unpruned trees (Table 5). The major increase in deposition came in targets placed at 0.7 and $1.5 \mathrm{~m}$ (Table 5); however, there were no significant differences among target heights. The difference between the inner and outer canopies was not significant (data not shown).

Table 4. Number and severity of infection periods from mid-March until mid-October according to Mills and LaPlante (30) in organic apple orchards at Nagykálló, Debrecen-Józsa, and Eperjeske, Hungary (2000-2002)

\begin{tabular}{lcccc}
\hline \multirow{2}{*}{$\begin{array}{c}\text { Location and } \\
\text { season }\end{array}$} & \multicolumn{3}{c}{ Severity of infection periods } & \\
\cline { 2 - 4 } & Low & Moderate & Severe & Total \\
\hline Nagykálló & 6 & 8 & & \\
2000 & 6 & 10 & 3 & 17 \\
2001 & 8 & 7 & 9 & 25 \\
2002 & & & 8 & 23 \\
Debrecen-Józsa & 5 & 9 & 3 & 17 \\
2000 & 4 & 6 & 8 & 25 \\
2001 & 10 & 7 & 9 & 24 \\
2002 & 5 & 10 & & \\
Eperjeske & 5 & 7 & 3 & 22 \\
2000 & 6 & & 6 & 21 \\
2001 & 9 & & & \\
2002 & & & & \\
\hline
\end{tabular}

Table 5. Percent coverage of spray deposition on paper targets placed in unpruned, weakly pruned, and strongly pruned apple trees in organic apple orchards (Nagykálló, Debrecen-Józsa, and Eperjeske, Hungary) on 2 May and 3 July 2002

\begin{tabular}{lccc}
\hline & \multicolumn{3}{c}{ Target height (m) } \\
\cline { 2 - 4 } & $\mathbf{0 . 7}$ & $\mathbf{1 . 5}$ & $\mathbf{2 . 2}$ \\
\hline 2 May & & & \\
Unpruned & $82^{\mathrm{x}} \mathrm{a}^{\mathrm{y}}$ & $83 \mathrm{a}$ & $76 \mathrm{a}$ \\
Weakly pruned & $86 \mathrm{a}$ & $85 \mathrm{a}$ & $79 \mathrm{a}$ \\
Strongly pruned & $91 \mathrm{a}$ & $88 \mathrm{a}$ & $81 \mathrm{a}$ \\
LSD $_{0.05}^{\mathrm{z}}$ & 10.5 & 8.9 & 11.8 \\
3 July & & $62 \mathrm{a}$ & $59 \mathrm{a}$ \\
Unpruned & $64 \mathrm{a}$ & $79 \mathrm{ab}$ & $65 \mathrm{ab}$ \\
Weakly pruned & $76 \mathrm{ab}$ & $81 \mathrm{~b}$ & $74 \mathrm{~b}$ \\
Strongly pruned & $83 \mathrm{~b}$ & 18.2 & 15.4 \\
LSD & 17.9 & &
\end{tabular}

${ }^{\mathrm{x}}$ Means of percent coverage of paper targets of the three orchards on unpruned, weakly pruned, and strongly pruned trees.

y Values within columns and application date followed by different letters are significantly different.

${ }^{\mathrm{z}}$ Means in each pruning treatment were compared using least significance difference (LSD) test at $P=$ 0.05 . erately susceptible, and resistant cultivars, respectively (Table 6). Pruning treatments significantly decreased development of leaf scab on the susceptible cultivars at all sites compared with that of unpruned treatments. For the susceptible cultivar Jonagold, AUDPC values of strongly pruned trees were significantly lower at $P$ $=0.05$ compared with either the weakly pruned or unpruned trees at Nagykálló and Debrecen-Józsa. However, the scabsusceptible cultivar Mutsu showed no significant differences between strongly and weakly pruned trees at Eperjeske in 2000, 2002 , or in the mean of the 3 years. AUDPC values of the moderately susceptible cultivars were also significantly lower on strongly pruned trees compared with unpruned ones. However, the differences between the weakly pruned and the unpruned trees were variable depending on year and site. Pruning treatments showed no effect on leaf scab development for the $V_{f}$-resistant apple cultivars, except for the year 2001 at Nagykálló.

AUDPC for fruit incidence. Analysis of variance of AUDPC values for fruit incidence (Table 8) were similar to analysis of AUDPC values for leaf incidence and indicated significant differences among pruning treatments $(P<0.05)$, among the three cultivars $(P<0.001)$, and among the 3 years $(P<0.001)$. There was a significant year $\times$ cultivar interaction at all sites and a significant cultivar $\times$ pruning interaction at Debrecen-Józsa, but this was much smaller than the main effect of year or cultivar.

For all cultivars and all sites, means of AUDPC values were less for fruit incidence compared with leaf incidence; they ranged from 769 to $1,457,132$ to 514 , and 0 to 19 percent-day for susceptible, moderately susceptible, and resistant cultivars, respectively (Table 7). The effect of pruning was smaller on development of fruit scab compared with that of leaf scab in all years and at all sites. Strong pruning treatments significantly decreased the means of AUDPC for fruit scab on susceptible cultivars compared with unpruned treatments in all sites. The effect of strong pruning treatments on moderately susceptible cultivars was significant only in 2001 at all sites. Resistant cultivars showed no significant effect of pruning treatments on development of fruit scab.

\section{DISCUSSION}

Pruning of apple trees enables management of tree shapes, increased growth of fruiting spurs, improved fruit coloration, and management of disease by the removal of diseased stems or dead wood that can harbor pathogens. The selective removal of branches also increases air movement within the tree canopy, which facilitates quicker drying of plant surfaces and a more uniform application of pesticides $(3,27,41,42)$. Although, in this study, val- 
ues of fruit and leaf scab incidence at harvest were high compared with a conventional or an integrated apple orchard $(16,19,29)$, our data indicated that pruning generally reduced the incidence of scab in organic apple production (Tables 6 and 7). However, the impact of pruning on disease varied widely for leaf and fruit and was also influenced by cultivar susceptibility and location. Depending on year and loca- tion, a susceptible cultivar showed greater effect of pruning on disease development than a moderately susceptible or a resistant cultivar. Moreover, the pruning treatments decreased the development of leaf scab more than that of fruit scab. Strong pruning significantly decreased the development of leaf scab on all susceptible and moderately susceptible cultivars at all sites and in almost all years, but the effect of pruning on the development of fruit scab was consistent only on scab-susceptible cultivars.

In some previous studies, the effect of pruning on plant diseases has been related to the different microclimates of pruned and unpruned plants. Cooley et al. $(4,5,7)$ indicated that the mode of action behind the decreased incidence of flyspeck in summer-pruned apple trees appeared to be

Table 6. Effect of pruning treatments on area under the disease progress curve (AUDPC) of leaf incidence for apple cultivars differing in susceptibility to apple scab in organic apple orchards at Nagykálló, Debrecen-Józsa, and Eperjeske, Hungary (2000-2002)

\begin{tabular}{|c|c|c|c|c|c|c|c|c|c|c|c|c|}
\hline \multirow{2}{*}{$\begin{array}{l}\text { Year and } \\
\text { cultivar }^{\mathrm{t}}\end{array}$} & \multicolumn{4}{|c|}{ Nagykálló } & \multicolumn{4}{|c|}{ Debrecen-Józsa } & \multicolumn{4}{|c|}{ Eperjeske } \\
\hline & Unpr. ${ }^{u}$ & Weak pr. & Strong pr. & $\operatorname{LSD}_{0.05}{ }^{v}$ & Unpr. & Weak pr. & Strong pr. & $\mathbf{L S D}_{\mathbf{0 . 0 5}}$ & Unpr. & Weak pr. & Strong pr. & $\mathbf{L S D}_{\mathbf{0 . 0 5}}$ \\
\hline \multicolumn{13}{|l|}{2000} \\
\hline Susceptible & $2550(46)^{\mathrm{w}} \mathrm{a}^{\mathrm{x}}$ & 2235 (44) b & $2024(41) \mathrm{c}$ & 195.1 & $2212(43) a$ & 1918 (39) b & $1734(36) \mathrm{c}$ & 184.3 & 2476 (44) a & $2212(42) b$ & 2098 (42) b & 189.4 \\
\hline Mod susc ${ }^{y}$ & $1112(27) \mathrm{a}$ & $973(24) \mathrm{b}$ & 905 (24) b & 160.4 & $1312(31) a$ & $1245(30) a b$ & 1175 (29) b & 154.2 & 1215 (29) a & $1165(29) \mathrm{ab}$ & $1098(27) b$ & 105.3 \\
\hline Resistant & 135 (4) a & 112 (4) a & 109 (3) a & 19.5 & $0(0)^{\mathrm{z}}$ & $0(0)$ & $0(0)$ & 0 & $0(0)$ & $0(0)$ & $0(0)$ & 0 \\
\hline \multicolumn{13}{|l|}{2001} \\
\hline Susceptible & 4252 (62) a & 3908 (58) b & $3649(55) \mathrm{c}$ & 239.5 & 3911 (59) a & $3723(57) \mathrm{b}$ & $3512(54) \mathrm{c}$ & 240.7 & 4692 (66) a & $4314(62) b$ & $4011(60) \mathrm{c}$ & 276.5 \\
\hline Mod susc & 1844 (38) a & $1672(35) b$ & $1628(36) \mathrm{b}$ & 133.2 & $1878(38) \mathrm{a}$ & $1711(36) b$ & $1675(36) b$ & 160.5 & $1935(40) \mathrm{a}$ & $1712(37) b$ & $1615(36) b$ & 195.7 \\
\hline Resistant & 203 (6) a & $172(5) a b$ & $170(5) \mathrm{b}$ & 30.2 & $19(0.5) \mathrm{a}$ & 32 (1) a & 24 (1) a & 20.2 & $0(0)$ & $0(0)$ & $0(0)$ & 0 \\
\hline \multicolumn{13}{|l|}{2002} \\
\hline Susceptible & $3516(54) \mathrm{a}$ & $3240(52) \mathrm{b}$ & $2945(50) \mathrm{c}$ & 183.7 & 3285 (52) a & $3001(50) \mathrm{b}$ & 2819 (48) c & 181.3 & 3915 (59) a & $3588(55) \mathrm{b}$ & $3495(55) b$ & 190.7 \\
\hline Mod susc & 1418 (32) a & $1312(30) b$ & $1251(30) \mathrm{b}$ & 112.8 & $1345(31) \mathrm{a}$ & $1210(30) \mathrm{ab}$ & $1157(28) b$ & 121.5 & 1432 (33) a & $1305(31) b$ & $1242(30) b$ & 120.7 \\
\hline Resistant & $210(6) \mathrm{a}$ & 198 (6) a & $185(6) \mathrm{a}$ & 49.6 & $0(0)$ & $0(0)$ & $0(0)$ & 0 & $32(2) \mathrm{a}$ & 24 (1) a & 39 (2) a & 19.2 \\
\hline \multicolumn{13}{|c|}{ Overall (2000-2002) } \\
\hline Susceptible & 3439 (54) a & $3128(51) b$ & $2873(49) \mathrm{c}$ & 204.5 & $3136(51) \mathrm{a}$ & $2881(48) b$ & $2688(46) \mathrm{c}$ & 202.4 & $3694(56) \mathrm{a}$ & $3371(53) b$ & $3201(52) b$ & 219.1 \\
\hline Mod susc & $1458(32) \mathrm{a}$ & $1319(30) \mathrm{b}$ & $1262(30) b$ & 136.8 & $1512(33) a$ & $1389(32) \mathrm{ab}$ & $1336(31) b$ & 146.7 & $1527(34) \mathrm{a}$ & $1394(32) \mathrm{ab}$ & $1318(31) b$ & 140.9 \\
\hline Resistant & $183(5) \mathrm{a}$ & $161(5) \mathrm{a}$ & $155(5) \mathrm{a}$ & 33.2 & $6.3(0.2) \mathrm{a}$ & $11(0.3) \mathrm{a}$ & $8(0.3) a$ & 6.5 & $11(0.7) \mathrm{a}$ & $8(0.3) a$ & $13(0.7) \mathrm{a}$ & 6.3 \\
\hline
\end{tabular}

${ }^{\mathrm{t}}$ Three cultivars differing in their susceptibility to apple scab were observed in all three orchards. Susceptible cultivars were Jonagold at Nagykálló and DebrecenJózsa, and Mutsu at Eperjeske; moderately susceptible cultivars were Elstar at Nagykálló and Debrecen-Józsa, and Idared at Eperjeske; and resistant cultivars were Liberty at Nagykálló and Prima at Debrecen-Józsa and Eperjeske.

" Unpr. = unpruned treatment; Weak pr. = weakly pruned treatment; and Strong pr. = strongly pruned treatment.

${ }^{v}$ Means in each pruning treatment were compared using least significance difference (LSD) test at $P=0.05$ for each cultivar and each site.

${ }^{w}$ Values in bracket are means of final leaf incidence in percentage assessed at fruit harvest time.

${ }^{x}$ Values within rows and locations followed by different letters are significantly different.

${ }^{\mathrm{y}}$ Moderately susceptible.

${ }^{\mathrm{z}}$ No scab symptoms were found in the treatment.

Table 7. Effect of pruning treatments on area under the disease progress curve (AUDPC) of fruit incidence for apple cultivars differing in susceptibility to apple scab in organic apple orchards at Nagykálló, Debrecen-Józsa, and Eperjeske, Hungary (2000-2002)

\begin{tabular}{|c|c|c|c|c|c|c|c|c|c|c|c|c|}
\hline \multirow{2}{*}{$\begin{array}{c}\text { Year and } \\
\text { cultivar }^{t}\end{array}$} & \multicolumn{4}{|c|}{ Nagykálló } & \multicolumn{4}{|c|}{ Debrecen-Józsa } & \multicolumn{4}{|c|}{ Eperjeske } \\
\hline & Unpr. ${ }^{u}$ & Weak pr. & Strong pr. & $\operatorname{LSD}_{0.05}{ }^{v}$ & Unpr. & Weak pr. & Strong pr. & $\mathbf{L S D}_{\mathbf{0 . 0 5}}$ & Unpr. & Weak pr. & Strong pr. & $\mathbf{L S D}_{0.05}$ \\
\hline \multicolumn{13}{|l|}{2000} \\
\hline Susceptible & $817(20)^{\mathrm{w}} \mathrm{a}^{\mathrm{x}}$ & 778 (19) a & $769(18) b$ & 45.3 & $922(22) \mathrm{a}$ & $858(20) b$ & $802(20) b$ & 62.1 & $1215(28) \mathrm{a}$ & $1148(28) a b$ & $1135(26) b$ & 75.7 \\
\hline Mod susc ${ }^{y}$ & $152(5) \mathrm{a}$ & $133(4) \mathrm{a}$ & $140(4) \mathrm{a}$ & 32.4 & $254(7) \mathrm{a}$ & $232(7) \mathrm{a}$ & $236(6) \mathrm{a}$ & 35.2 & $165(4) \mathrm{a}$ & $142(4) \mathrm{a}$ & $148(4) \mathrm{a}$ & 25.6 \\
\hline Resistant & $0(0)^{\mathrm{z}}$ & $0(0)$ & $0(0)$ & 0 & $0(0)$ & $0(0)$ & $0(0)$ & 0 & $0(0)$ & $0(0)$ & $0(0)$ & 0 \\
\hline \multicolumn{13}{|l|}{2001} \\
\hline Susceptible & $1355(28) \mathrm{a}$ & $1323(28) \mathrm{ab}$ & $1234(27) \mathrm{b}$ & 110.1 & $1242(28) \mathrm{a}$ & $1155(27) b$ & $1129(26) \mathrm{b}$ & 80.4 & $1457(30) \mathrm{a}$ & $1382(30) \mathrm{ab}$ & $1342(29) \mathrm{b}$ & 105.3 \\
\hline Mod susc & 448 (12) a & $422(11) \mathrm{ab}$ & $400(10) b$ & 45.3 & $514(13) \mathrm{a}$ & 485 (12) ab & 457 (11) b & 43.6 & $195(6) \mathrm{a}$ & $167(5) a b$ & $161(4) b$ & 30.4 \\
\hline Resistant & $11(0.3) \mathrm{a}$ & $19(0.4) \mathrm{a}$ & $14(0.4) \mathrm{a}$ & 6.4 & $0(0)$ & $0(0)$ & $0(0)$ & 0 & $0(0)$ & $0(0)$ & $0(0)$ & 0 \\
\hline \multicolumn{13}{|l|}{2002} \\
\hline Susceptible & $1188(27) \mathrm{a}$ & $1117(26) \mathrm{ab}$ & $1036(24) b$ & 132.7 & 914 (22) a & $875(20) a b$ & $849(20) b$ & 55.1 & $912(22) \mathrm{a}$ & $902(21) a b$ & $875(20) b$ & 34.3 \\
\hline Mod susc & $402(10) \mathrm{a}$ & 359 (9) a & $358(10) \mathrm{a}$ & 58.6 & $425(11) \mathrm{a}$ & $399(10) \mathrm{a}$ & 411 (9) a & 42.5 & $151(4) \mathrm{a}$ & $132(4) \mathrm{a}$ & $139(4) \mathrm{a}$ & 21.3 \\
\hline Resistant & $0(0)$ & $0(0)$ & $0(0)$ & 0 & $0(0)$ & $0(0)$ & $0(0)$ & 0 & $0(0)$ & $0(0)$ & $0(0)$ & 0 \\
\hline \multicolumn{13}{|c|}{ Overall (2000-2002) } \\
\hline Susceptible & $1118(25) \mathrm{a}$ & $1073(24) \mathrm{ab}$ & $1013(23) \mathrm{b}$ & 102.6 & $1026(24) \mathrm{a}$ & $963(22) a b$ & $927(22) b$ & 64.7 & $1195(27) \mathrm{a}$ & $1144(26) \mathrm{ab}$ & $1117(25) b$ & 71.9 \\
\hline Mod susc & $334(9) \mathrm{a}$ & $305(8) \mathrm{a}$ & $299(8) \mathrm{a}$ & 45.8 & $398(10) \mathrm{a}$ & $372(10) \mathrm{a}$ & $368(9) \mathrm{a}$ & 40.6 & $170(5) \mathrm{a}$ & 147 (4) a & 149 (4) a & 25.5 \\
\hline Resistant & $5(0.1) \mathrm{a}$ & $6(0.1) \mathrm{a}$ & $5(0.1) \mathrm{a}$ & 2.1 & $0(0)$ & $0(0)$ & $0(0)$ & 0 & $0(0)$ & $0(0)$ & $0(0)$ & 0 \\
\hline
\end{tabular}

${ }^{\mathrm{t}}$ Three cultivars differing in their susceptibility to apple scab were observed in all three orchards. Susceptible cultivars were Jonagold at Nagykálló and DebrecenJózsa, and Mutsu at Eperjeske; moderately susceptible cultivars were Elstar at Nagykálló and Debrecen-Józsa, and Idared at Eperjeske; and resistant cultivars were Liberty at Nagykálló and Prima at Debrecen-Józsa and Eperjeske.

${ }^{\mathrm{u}}$ Unpr. = unpruned treatment; Weak pr. = weakly pruned treatment; and Strong pr. = strongly pruned treatment.

${ }^{\mathrm{v}}$ Means in each pruning treatment were compared using least significance difference (LSD) test at $P=0.05$ for each cultivar and each site.

${ }^{\mathrm{w}}$ Values in bracket are means of final fruit incidence in percentage assessed at fruit harvest time.

$\mathrm{x}$ Values within rows and locations followed by different letters are significantly different.

y Moderately susceptible.

${ }^{\mathrm{z}}$ No scab symptoms were found in the treatment. 
related to the difference in the moisture content of air in the canopy. Gubler et al. (15), English et al. (11), and Houma et al. (22) demonstrated that Botrytis bunch rot of grape can be suppressed by the removal of leaves from around flower clusters. This reduction in disease was related to different microclimate parameters, with wind speed being the most important. However, for the most part, differences in disease incidence and severity have been difficult to explain based on measured differences in environmental factors such as temperature, relative humidity, or wetness duration. This study on apple showed that there were no consistent differences between temperature and relative humidity as monitored by hygrothermographs placed in the canopies of a strongly winter-pruned and an unpruned tree. In low-density apple orchards, Ocamb-Basu et al. (33) reported that sooty blotch severity of fruits at harvest averaged $9 \%$ less in winter-pruned trees than in unpruned ones. As in this study, they indicated that there were no consistent differences in temperature and relative humidity between pruned and unpruned trees. Savage and Sall (36) demonstrated that Botrytis fruit rot of grape was $47 \%$ greater on vines trained to a cross-arm style trellis than vines trained to a two-wire vertical trellis, respectively. However, only subtle differences in temperature or moisture regimes were associated with the change in trellis type or pruning treatments and change in disease incidence or severity. Moreover, it needs to be emphasized that $\mathrm{RH}$ and temperature are relatively conserved spatially in crop canopies; whereas the duration of leaf wetness (LWD) is far more variable spatially $(13,28,40)$. In-canopy comparisons of LWD were not made among the pruning treatments in this study. In agreement with
Savage and Sall (36) and Ocamb-Basu et al. (33), we assume that pruning alters the microclimate of leaves or fruits by increasing air movement and light penetration, and in this way decreases the length of periods of wetness or high RH. These effects might also play a role in the reduction of apple scab development on leaves and fruits. Moreover, we assume that the reduction in disease observed may also be a result of more efficient fungicide deposition in pruned trees (Table 5). In agreement with our study, research in North Carolina found that spray deposition was greater and less variable on leaves in wellpruned trees than in unpruned ones $(41,43,44)$. This is probably a result of more uniform penetration and distribution of sprayed material. Although fungicide deposition on fruit was not measured, it is reasonable to expect the same effect. Thus, improved spray penetration resulting from pruning is likely to supplement a possible micro-environmental difference in LWD, which may result in the reduction of leaf and fruit scab in dwarf trees in well-pruned organic apple orchards.

Differences in the effect of pruning on scab development of fruit and leaf in organic apple orchards may be due to the differences in their infection characteristics during the season. One- to four-day-old unfolded leaves are the most susceptible to the disease. With each passing day from this point, infection efficiency on leaves exponentially decreases with the ageing of the leaves $(31,38)$. New leaves unfold from spring throughout the season; therefore, susceptible leaves are always present in the tree canopy, which allows for new infections if environmental conditions are favorable. However, fruits are the most susceptible until 2 to 4 weeks after fruit set; then a continuously increasing ontogenetic resistance forms with the ageing of the fruits (39). Moreover, new fruits normally set only once a year; therefore, all fruits decrease in their susceptibility throughout the season. Until 2 to 4 weeks after fruit set, differences in spray deposition are only subtle between pruned and unpruned trees (Table 5), because leaf size is smaller and leaf number is lower than later in the season. Therefore, during the most susceptible phase of fruit development, circumstances for infection are similar in the pruned and unpruned trees. This may explain the finding that pruning had only a small effect on fruit scab epidemics (Table 7). However, the amount of foliar disease is greater on an unpruned tree than on a pruned one (Table 6) because young, susceptible leaves are present almost the entire season in the tree canopy. Furthermore, spray deposition on a pruned tree may be reduced and LWD increased in midseason, when leaves are fully unfolded, compared with early in the season, when leaves are small.

Today, sustainable fruit production is based on integrated and organic production guidelines. Growers are allowed to use synthetic fungicides in integrated fruit production. Thus, scab incidence can be held under a damage threshold level, even on a scab-susceptible apple cultivar $(19,29)$. At the same three locations where the present study was made, the effect of winter pruning on apple scab was also investigated under a general integrated disease management practice on the same six apple cultivars. The results showed that the incidence of leaf and fruit scab was lower only on scab-susceptible cvs. Jonagold and Mutsu on strongly pruned trees compared with unpruned ones, although it was significant $(P=0.05)$ only in 2001 and 2002 (I. J. Holb, unpublished). The

Table 8. Analyses of variance (ANOVA) for effects of year, cultivar, and pruning on area under the disease progress curve (AUDPC) of leaf scab incidence and fruit scab incidence in organic apple orchards at Nagykálló, Debrecen-Józsa, and Eperjeske, Hungary over 2000-2002

\begin{tabular}{|c|c|c|c|c|c|c|c|}
\hline \multirow[b]{2}{*}{ Source of variation } & \multirow[b]{2}{*}{ df } & \multicolumn{2}{|c|}{ Nagykálló } & \multicolumn{2}{|c|}{ Debrecen-Józsa } & \multicolumn{2}{|c|}{ Eperjeske } \\
\hline & & Mean square & $F$ value $^{z}$ & Mean square & $F$ value & Mean square & $F$ value \\
\hline \multicolumn{8}{|l|}{ Leaf } \\
\hline Year & 2 & $6,011,297$ & $586.3 * * *$ & $5,279,112$ & $695.1 * * *$ & $7,233,359$ & $702.9 * * *$ \\
\hline Cultivar & 2 & $81,144,521$ & $7,914.7 * * *$ & $75,364,349$ & $9,922.1 * * *$ & $105,456,219$ & $10,288.5 * * *$ \\
\hline Pruning & 2 & 634,204 & $61.5 * * *$ & 511,431 & $58.3 * * *$ & 505,615 & $49.1 * *$ \\
\hline Year $\times$ cultivar & 4 & $1,979,554$ & $193.1 * * *$ & $2,174,214$ & $223.2 * * *$ & $3,688,517$ & $358.4 * * *$ \\
\hline Year $\times$ pruning & 4 & 2,489 & 0.3 & 37 & 0.0 & 22,683 & 2.2 \\
\hline Cultivar $\times$ pruning & 4 & 228,688 & $22.3 * *$ & 155,218 & $20.4 *$ & 190,834 & $18.5 * *$ \\
\hline Year $\times$ cultivar $\times$ pruning & 8 & 968 & 0.1 & 3,048 & 0.4 & 8,370 & 0.8 \\
\hline Residual & 81 & 10,250 & & 7,595 & & 10,291 & \\
\hline Total & 107 & & & & & & \\
\hline \multicolumn{8}{|l|}{ Fruit } \\
\hline Year & 2 & 694,487 & $419.1 * * *$ & 323,654 & $249.7 * * *$ & 282,286 & $216.8 * * *$ \\
\hline Cultivar & 2 & $10,767,916$ & $6,498.4 * * *$ & $8,635,702$ & $6,662.7 * * *$ & $14,065,218$ & $10,802.4 * * *$ \\
\hline Pruning & 2 & 19,144 & $8.6 *$ & 27,441 & $15.4 * *$ & 10,492 & $8.0 *$ \\
\hline Year $\times$ cultivar & 4 & 201,052 & $121.3 * *$ & 119,682 & $92.3 * *$ & 232,527 & $148.6 * *$ \\
\hline Year $\times$ pruning & 4 & 2,324 & 1.4 & 732 & 0.6 & 990 & 0.7 \\
\hline Cultivar $\times$ pruning & 4 & 7,070 & 3.7 & 8,070 & $6.9 *$ & 5,004 & 3.8 \\
\hline Year $\times$ cultivar $\times$ pruning & 8 & 1,014 & 0.6 & 566 & 0.4 & 562 & 0.4 \\
\hline Residual & 81 & 1,657 & & 1,296 & & 1,296 & \\
\hline Total & 107 & & & & & & \\
\hline
\end{tabular}

${ }^{\mathrm{z}}$ Values followed by $*, * *$, and $* * *$ are statistically significant at $P<0.05,0.01$, and 0.001 , respectively. 
small effect of pruning on apple scab in the integrated orchards was probably due to the effectiveness of spray schedules and the low PAD values of the experimental plots. However, because fungicides are not as effective in organic apple production, other management practices might play an important role in disease management $(10,17-19,29)$. In organic apple orchards, the risk of a scab epidemic is often high because the PAD is often high in spring (17-19). Value of PAD is dependent primarily on the amount of scab on leaves in autumn, and they are positively correlated with each other (12). Therefore, decrease of scab on leaves in autumn results in lower primary inoculum (PAD) in spring. This study showed that winter pruning, especially strong winter pruning, could reduce the amount of leaf scab until harvest and resulted in lower AUDPC on pruned trees than on unpruned ones (Table 8). Consequently, PAD might be lower in spring in a well-pruned apple orchard than in a weakly pruned or an unpruned one. Moreover, Holb et al. $(20,21)$ demonstrated that scab conidia could overwinter inside buds in most organic orchards and cause early scab epidemics before the period of ascospore infection; and it was also shown that these overwintered conidia could be effectively reduced by pruning of the upper third part of the last year's extension shoots before bud break. The authors noted that this winter pruning could be crucial in organic apple orchards where scab incidence in autumn is above $40 \%$, because the effect of usual fungicide applications at bud break might be partial, as most of the fungicides used in organic orchards are "contact", and consequently, it might be difficult to reach conidia inside buds and prevent infection. Therefore, pruning of apple trees as a management tactic for control of apple scab might act via three possible mechanisms: removal of overwintered conidia inside buds, improvement of spray penetration, or modification of in-canopy microclimate. However, more research is needed to determine which mechanism is the key one in disease reduction by winter tree pruning in organic apple orchards.

\section{ACKNOWLEDGMENTS}

I thank Troy B. Wiwczaroski (University of Debrecen, Centre of Agricultural Sciences) and József Gáll (University of Debrecen, Institute of Mathematics and Informatics) for their critical reading of the manuscript and valuable suggestions. Thanks are also due to the following growers and farm managers for their cooperation: F. Abonyi, I. Medgyessy, and J. Katona. This research was supported partly by a grant of the Hungarian Scientific Research Fund (OTKA F043503) and a János Bolyai Research Fellowship awarded to I. J. Holb.

\section{LITERATURE CITED}

1. Anonymous. 1997. Guidelines for organic crop production. Association for Hungarian Organic Production, Budapest, Hungary. (in Hungarian)

2. Campbell, C. L., and Madden, L. V. 1990.
Introduction to Plant Disease Epidemiology. John Wiley \& Sons, New York.

3. Childers, N. F. 1973. Modern Fruit Science. Horticultural Publications Rutgers University, The State University, New Brunswick, NJ.

4. Cooley, D. R., Autio, W. R., and Gamble, J. W. 1992. Second-level apple integrated pest management: The effects of summer pruning and a single fungicide application on flyspeck and sooty blotch. Fruit Notes 57(1):16-17.

5. Cooley, D. R., Gamble, J. W., and Autio, W. R. 1997. Summer pruning as a method for reducing flyspeck disease on apple fruit. Plant Dis. 81:1123-1126.

6. Cooley, D. R., Gamble, J. W., and Mazzola, M. 1991. Effects of sulfur and copper fungicides on fruit finish, scab, and soil acidity. Fruit Notes 56(1):22-23.

7. Cooley, D. R., Telgheder, C., Autio, W. A., and Gamble, J. 1992. Using summer pruning to reduce flyspeck and sooty blotch of apple in the Northeast. (Abstr.) Phytopathology 82:1075.

8. Crosby, J. A., Janik, J., Pecknold, P. C., Korban, S. S., O'Connor, P. A., Ries, S. M., Goffreda, J., and Voordeckers, A. 1992. Breeding apples for scab resistance: 1945-1990. Fruit Var. J. 46(3):145-166.

9. Drinkwater, L. E., Workneh, F., Letourneau, D. K., Van Bruggen, A. H. C., and Shennan, C. 1995. Fundamental differences in organic and conventional agroecosystems in California. Ecol. Appl. 5:1098-1112.

10. Ellis, M. A., Ferree, D. C., Funt, R. C., and Madden, L. V. 1998. Effects of an apple scabresistant cultivar on use patterns of inorganic and organic fungicides and economics of disease control. Plant Dis. 82:428-433.

11. English, J. T., Thomas, C. S., Marois, J. J., and Gubler, W. D. 1989. Microclimates of grapevine canopies associated with leaf removal and control of Botrytis bunch rot. Phytopathology 79:395-401.

12. Gadoury, D. M., and MacHardy, W. E. 1986. Forecasting ascospore dose of Venturia inaequalis in commercial apple orchards. Phytopathology 76:112-118.

13. Gleason, M. L., Taylor, S. E., Loughin, T. M., and Koehler, K. J. 1994. Development and validation of an empirical model to estimate the duration of dew periods. Plant Dis. 78:1011-1016.

14. Gomez, K. A., and Gomez, A. A. 1984. Statistical Procedures for Agricultural Research. John Wiley \& Sons, New York.

15. Gubler, W. D., Marois, J. J., Bledsoe, A. M., and Bettiga, L. J. 1987. Control of Botrytis bunch rot of rape with canopy management. Plant Dis. 71:599-601.

16. Holb, I. J. 2000. Disease progress of apple scab caused by Venturia inaequalis in environmentally friendly growing systems. Int. J. Hortic. Sci. 6(4):56-62.

17. Holb, I. J., de Jong, P. F., and Heijne, B. 2003. Efficacy and phytotoxicity of lime sulphur in organic apple production. Ann. Appl. Biol. 142:225-233.

18. Holb, I. J., and Heijne, B. 2001. Evaluating primary scab control in organic apple production. Gartenbauwissenschaft 66:254-261.

19. Holb, I. J., Heijne, B., and Jeger, M. J. 2003. Summer epidemics of apple scab: The relationship between measurements and their implications for the development of predictive models and threshold levels under different disease control regimes. J. Phytopathol. 151(6):335-343.

20. Holb, I. J., Heijne, B., and Jeger, M. J. 2004. Overwintering of conidia of Venturia inaequalis and the contribution to early epidemics of apple scab. Plant Dis. 88:751-757.

21. Holb, I. J., Heijne, B., and Jeger, M. J. 2005. The widespread occurrence of overwintered conidial inoculum of Venturia inaequalis on shoots and buds in organic and integrated ap- ple orchards across the Netherlands. Eur. J. Plant Pathol. 111(2):157-168.

22. Houma, A. R., Cherif, M., and Boubaker, A. 1998. Effect of nitrogen fertilizing, green pruning and fungicide treatments on Botrytis bunch rot of grapes. J. Plant Pathol. 80(2):115-124.

23. IFOAM. 1989. Basic Standards for Organic Agriculture. Tholey-Theley Press, New York.

24. IFOAM. 1998. Basic Standards for Organic Production and Processing. Tholey-Theley Press, New York.

25. IFOAM. 2000. IFOAM Basic Standards for Organic Production and Processing. TholeyTheley Press, New York.

26. Lamb, R. C., Aldwinckle, H. S., Way, R. D., and Terry, D. E. 1979. "Liberty" apple. HortScience 14:757-758.

27. Latham, A. J., and Hollingsworth, M. H. 1973. Incidence and control of sooty blotch and flyspeck of apples in Alabama. Auburn Univ. Agric. Exp. Stn. Circ. 208.

28. Laurence, H., Fabry, F., Dutilleul, P., Bourgeois, G., and Zawadzki, I. 2002. Estimation of the spatial pattern of surface relative humidity using ground based radar measurements and its application to disease risk assessment. Agric. For. Meteorol. 111:223-231.

29. MacHardy, W. E. 1996. Apple Scab: Biology, Epidemiology, and Management. American Phytopathological Society, St. Paul, MN.

30. Mills, W. D., and La Plante, A. A. 1951. Diseases and insects in the orchard. Cornell Ext. Bull. 711

31. Moore, M. H. 1964. Glasshouse experiments on apple scab. I. Foliage infection in relation to wet and dry periods. Ann. Appl. Biol. 53:423435.

32. Norton, R. A. 1981. Field susceptibilty of apple cultivars to scab, Venturia inaequalis, and powdery mildew, Podosphaera leucotricha in a cool, humid climate. Fruit Var. J. 32:2-5.

33. Ocamb-Basu, C. M., Sutton, T. B., and Nelson, L. A. 1988. The effects of pruning on incidence and severity of Zygophiala jamaicensis and Gloeodes pomigena infections of apple fruit. Phytopathology 78:1004-1008.

34. Pedersen, L. H., and Christensen, J. V. 1994 The influence of integrated and organic spraying programs on the incidence on scab (Venturia inaequalis Cooke) on 11 apple cultivars Norw. J. Agric. Sci., Suppl. 17:261-266.

35. Reganold, J. P., Glover, J. D., Andrews, P. K., and Hinman, H. R. 2001. Sustainability of three apple production systems. Nature 410:926-930.

36. Savage, S. D., and Sall, M. A. 1984. Botrytis bunch rot of grapes: Influence of trellis type and canopy microclimate. Phytopathology 74:65-70.

37. Schnabel, G., and Layne, D. R. 2004. Comparison of reduced-application and sulfurbased fungicide programs on scab intensity, fruit quality, and cost of disease control on peach. Plant Dis. 88:162-166.

38. Schwabe, W. F. S. 1979. Changes in scab susceptibility of apple leaves as influenced by age. Phytophylactica 11:53-56.

39. Schwabe, W. F. S., Jones, A. L., and Jonker, J. P. 1984. Changes in the susceptibility of developing apple fruit to Venturia inaequalis. Phytopathology 74:118-121.

40. Sentelhas, P. C., Gillespie, T. J., Gleason, M L., Monteiro, J.-E. B. A., and Helland, S. T. 2004. Operational exposure of leaf wetness sensors. Agric. For. Meteorol. 126:59-72.

41. Sutton, T. B., and Unrath, C. R. 1984. Evaluation of the tree-row-volume concept with density adjustments in relation to spray deposits in apple orchards. Plant Dis. 68:480-484.

42. Teskey, B. J. E., and Shoemaker, J. S. 1978. Tree Fruit Production. AVI Publishing Company, Westpart, CT.

43. Travis, J. W. 1981. Factors affecting pesticide distribution in apple trees. Ph.D. thesis. North 
Carolina State University, Raleigh.

44. Travis, J. W., Skroch, W. A., and Sutton, T. B. 1987. Effect of canopy density on pesticide deposition and distribution in Golden delicious apple trees. Plant Dis. 71:613-615.

45. Weibel, F., and Häseli, A. 2003. Organic apple production - with emphasis on European ex- periences. Pages 551-583 in: Apples: Botany, Production and Uses. D. C. Ferree and I. J. Warrington, eds. CAB International, Wallingford, UK.

46. Weiss, A., Hipps, L. E., Blad, B. L., and Steadman, J. R. 1980. Comparison of withincanopy microclimate and white mold disease
(Sclerotinia sclerotiorum) development in dry edible beans as influenced by canopy structure and irrigation. Agric. Meteorol. 22:11-22.

47. Williams, E. B., Dayton, D. F., and Shay, J. R 1966. Allelic genes in Malus for resistance to Venturia inaequalis. Proc. Am. Soc. Hortic. Sci. 88:52-56. 